\title{
Farmers' spatial behaviour, demographic density dependence and the spread of Neolithic agriculture in Central Europe
}

\author{
Serge Svizzero \\ Faculté de Droit et d'Economie, Université de La Réunion, FR \\ serge.svizzero@univ-reunion.fr
}

\begin{abstract}
Since the early 1970s, the demic diffusion model has been the cornerstone of the migrationist approach to European Neolithisation. It considers the latter as a slow, gradual and haphazard process. During the last decade, its relevance has been challenged by the observed variability of the expansion, such as the extreme example exhibited by LBK expansion in Central Europe. To account for it, migration - which is usually explained by exogenous push-pull factors - must rather be viewed as the result of farmers' spatial behaviour. We adopt this approach and highlight the influence of agglomeration effects and the Allee effect in settled areas on farmers' choice of location, an influence which also leads to defining migration as endogenous. Both effects - which find support in archaeological records - exhibit demographic density dependence and help to explain an observed but counter-intuitive result. Indeed, high demographic density is associated with a slower rate of expansion of farming; this may result from strong agglomeration and Allee effects, which hinder - or even prevent - the migratory spread of agriculture. Farmers' cooperation with indigenous populations leads to the acculturation of the latter and, therefore, may reduce the influence of both effects, fostering farmers' migration.
\end{abstract}

IZVLEČEK - Že od začetka sedemdesetih let prejšnjega stoletja je model demske difuzije eden od temeljev migracijskih pristopov $k$ neolitizaciji Evrope. Koncipiran je kot počasen, postopen in neorganiziran proces. $V$ zadnjem desetletju so njegovo relevantnost spodkopale opažene razlike $v$ hitrosti širjenja, kot recimo ekstremni primer širitve LTK v srednji Evropi. Da bi jo ustrezno upoštevali, moramo migracije, ki so običajno razložene z zunanjimi 'push' in 'pull' faktorji, razumeti kot odraz prostorskega vedenja kmetovalcev. V prispevku uporabimo ta pristop in osvetlimo vpliv učinka aglomeracije in Alleejevega učinka v izbranih kmetijskih poselitvenih območjih. Ti vplivi gibalo migracij postavljajo med notranje vzroke. Oba učinka, za katera lahko najdemo dokaze v arheološkem zapisu, sta odvisna od demografske gostote in pomagata razumeti opažene rezultate, ki niso intuitivno jasni. Izkaže se, da je večja demografska gostota povezana s počasnejšim razširjanjem kmetovanja; to je najbrž rezultat močnega aglomeracijskega in Allejevega učinka, ki zavira - ali celo preprečuje - migracijsko širjenje kmetijstva. Sodelovanje kmetovalcev z domorodnimi skupnostmi vodi $k$ akulturaciji domorodcev in omejuje vpliv obeh učinkov, kar spodbuja migracije kmetovalcev.

KEY WORDS - agglomeration economies; Allee effect; demographic density; LBK culture; migration; palaeo-economy

\section{Introduction}

Since Gordon V. Childe's (1936) original conceptualisation, the introduction of agriculture into Europe has been thought to reflect the spread of incoming farmers bringing the so-called 'Neolithic package', i.e. animals and domestic plants, ceramic containers, storage facilities, new architecture and elaborate bu- rials rituals. Indeed, based on similarities at early Neolithic sites across Europe, Childe first proposed that the patterns exhibited were not consistent with the diffusion of Neolithic practices from southwest Asia, but rather the movement of agriculturalists. In Europe, agriculture spread in approximately 2500 
years from South-East Europe (Thessaly, 6500 BC) 1 to Scandinavia, Britain and Ireland (around 4000 $\mathrm{BC})$. The apparent regularity of this spread, along with the monotonic cline in dates for the earliest Neolithic across Europe from the southeast to northwest, has led subsequent researchers to adopt a view similar to Childe's. Among these contributions, the most famous is the demic diffusion model (Ammerman, Cavalli-Sforza 1971; 1984) and its associated 'wave of advance'. Demic diffusion is in fact a kind of cumulative short-distance movement requiring no human motivation, intentionality, or agency at the macro level, or as Albert J. Ammerman and Luigi L. Cavalli-Sforza themselves put it (1984.68), 'a form of colonization without colonists'. The demic diffusion model is based on Ronald Fisher's (1937) reaction-diffusion equation. According to this model, the entire diffusion process, from Greece to the British Isles, took place in about 2500 years, i.e. it proposes that agriculture spread in Europe at an average speed of one kilometre per year, or 25 kilometres per generation. ${ }^{2}$ However, when Ammerman and Cavalli-Sforza (1971) derived the rate of spread to be $1 \mathrm{~km} /$ year on average in Europe, they also noted very significant regional variations in the rate. This is not surprising when the heterogeneity of the spatial domain, Europe, is considered. For example, unfavourable ecological and geographical factors caused a retardation of the spread to the Alps; similarly retarded movement occurs at latitudes above $54^{\circ}$ North due to the unsuitable climatic conditions. Unlike the previous slow speed, in Central Europe the propagation path of the $\mathrm{LBK}^{3}$ culture had an increased propagation speed along the Danube and Rhine valleys, as did the spread of the Cardial-Impressa cultures along the Mediterranean coast. According to various estimates, the speeds of propagation of the wave front in these diverse areas are as follows: $1 \mathrm{~km} / \mathrm{yr}$ on average in Europe, $4-6 \mathrm{~km} / \mathrm{yr}$ for the Danube-Rhine valleys, $10 \mathrm{~km} / \mathrm{yr}$ in Mediterranean coastal regions (Zilhão 2001).

\section{The regional variability of the spread}

It is thus clear that farmers' migration into Europe ${ }^{4}$ did not occur in a uniform way; indeed, spatial variations in the propagation speed of the land farmers have been noted in many publications (Price 2000; Gkiasta et al. 2003; Rowley-Conwy 2011; Fort 2015). While demic diffusion may describe the overall patterning of the European dataset particularly well, when viewed at a regional scale very few regions appear to be the result of merging communities and the slow expansion of a wave of agriculturalists. When looking at site patterning for the earliest Neolithic in many regions of Europe, a more stochastic pattern of agricultural spread emerges (Price 2000). As stated by Rowley-Conwy (2011.S443), "We must replace the monolithic 'wave of advance' concept with a series of local and disparate 'lurches of advance".

When the spread of agriculture is measured at a spatial and temporal micro scale, its observed variability may even be very important. For instance, Detlef Gronenborn (2003.81) argues for an LBK migration covering $800 \mathrm{~km}$ in 100 years, between Transdanubia and western Central Europe. At the other extreme of the spectrum is the fact that, while LBK materials spread from Hungary to southern Holland and northern Germany within a hundred years, its explosive movement stopped before it reached the Atlantic and Baltic coasts. In these regions, the period from first contact between indigenous huntergatherers (Ertebølle) 5 and agricultural groups (LBK and subsequent cultures to TRB ${ }^{6}$ ) to the full adoption of agricultural practices in Northern Europe extends over more than 1500 years. There is thus a disparity between artefacts and agriculture: 1500 years of artefact exchange led to no economic Neolithisation. The first evidence for the Neolithic in Scandinavia appears around $4000 \mathrm{BC}$ in the form of the TRB culture (Svizzero 2015). Such observed extreme

1 Dates listed as BC are in calibrated years.

2 It should be noted that in their initial work, Ammerman and Cavalli-Sforza (1971) studied 53 early Neolithic sites and derived a speed range of $0.6-1.1 \mathrm{~km} / \mathrm{yr}$. More recent studies using a larger sample of radiocarbon dates have confirmed this initial result: e.g. Pinhasi et al. (2005) consider 753 early Neolithic sites and derive a speed range of 0.6-1.3 km/yr.

3 Many archaeologists continue to use the German name Linearbandkeramik (LBK) or Linienbandkeramik or sometimes simply Bandkeramik. The English translation, also frequently seen in archaeological literature, is Linear Pottery culture.

4 This view also includes the recognition of local and regional variability in the LBK package (Bentley 2007) which was, until recently, considered as particularly homogeneous.

5 The Mesolithic Ertebølle culture is found 5400-3950 BC in the western Baltic area (southern Sweden, Denmark, and northern Germany between the Elbe and the Oder Rivers) and is contemporary with the LBK.

6 The LBK disappeared from Central Europe at the beginning of the $5^{\text {th }}$ millennium and various Neolithic groups developed in the areas previously occupied by LBK populations. Among these various Neolithic groups the Funnel Beaker Culture, also called TRB (TRB for the abbreviation of its German name, Tricherrandbecher or Trichterbecher) appeared around $4000 \mathrm{BC}$. People of the TRB culture were the first farmers of much of Northern Europe. 
variability leads some authors (Bogucki 2000; Fiedel, Anthony 2003; Shennan 2007; 2009; Kind 2010 ) to reject commonly used models to explain the Neolithisation of Central Europe. The demic diffusion model as well as agriculture diffusion by leapfrog7 colonisation has been excluded because they are not consistent with rapid colonisation. Similarly, massive or 'folk' migration as well as long-distance migration are rejected because such migrations require an important logistic and tend to cross an ecological or cultural boundary and involve extensive planning and the risk of permanently breaking ties with the homeland population, all of which hinders the rate of expansion (Fiedel, Anthony 2003).

\section{From demic diffusion to farmers' spatial be- haviour}

The rapid colonisation of some areas implies a major change in the framework used by scholars to study the spread of agriculture. Since farmers' migrate rapidly, they must have done so before their population came close to its absolute local carrying capacity. Therefore, farmers' migration was probably not the result of a combination of negative stresses - the so-called 'push factors' used in migration theory - such as population growth and resource depletion in areas under domestication, but more likely triggered by positive attractions - pull factors - in the immigration area, such as the search for uninhabited and arable land. In other words, the link between human migration and the spread of agriculture should not be only viewed at the macro-scale e.g. the entire European continent - as the demic diffusion model assumes. On the contrary, it should also be viewed at a more restricted or local scale, e.g. the 'site level'. According to this latter approach, migration is now viewed as the result of farmers' spatial behaviour8 (Bogucki 2000; Fiedel, Anthony 2003; Shennan 2007; 2009; Kind 2010). Thus, even for early farming groups, decisions on where to settle were highly selective rather than proceeding from a random-walk process, as described by the wave of advance model. Early farmers chose to settle only in optimal areas, with high soil fertility and moisture content. Consequently, the initial spread of farming was not uniform, with early farmers 'leap-frogging' from one niche environment to another, i.e. involving instead the infilling of optimal areas within a region through the spread of the daughter settlements to sites comparable to those occupied by their mother settlements (van Andel, Runnels 1995).

It should be noted that this approach also finds support in spatial aspects of migratory theory. Among the theoretical characteristics of migration, Everett S. Lee (1966) considers that the most influential is the concept that migration is selective. Moreover, it would be expected traditionally that the probability of migration decreases as the distance between two places increases, as a result of the greater risk involved in migrating over larger distances. Gareth J. Lewis (1982) recognised that the majority of modern migration events, and presumably in prehistory, were over short distances within a local area. 9 This belief is reinforced by the fact that social connections between migrants and populations in the homeland form an essential component of the migration process, i.e. they are thought to influence the spatial limits of migration.

The purpose of this paper is thus to study the spatial behaviour of farmers and the resulting migratory movements. More precisely, we try to identify the main factors which influence farmers' decision about whether to migrate or not, and which therefore are able to explain the regional and temporal variability in the rate of expansion of the farming system. We identify three factors, related respectively to soils fertility, agglomeration effects - i.e. economic forces affecting geographical concentration - and the conditions of farmers' reproduction and survival. These three factors have a common thread: their influence on farmers' spatial behaviour is mediated by demographic density (defined at the site level). While a high demographic density fosters migration through the first factor, it hinders it (or may even prevent it) throughout the two other factors. While the first factor is quite common in the literature related to agriculture diffusion, the two others are not. Since they lead to a negative correlation between the rate of farming expansion and demographic density, they contribute to explaining this counter-intuitive correlation exhibited for instance by Jean-Pierre Bocquet-Appel et al. (2012).

\footnotetext{
7 It should be noted that other scholars consider that the colonization of Central Europe by farmers occurred through 'leapfrog colonization'; see e.g., Marek Zvelebil (2001.5).

8 Human Behavioural Ecology provides tools and concepts suited to analyze optimal behavior related to, for instance, location or foraging (see Winterhalder, Kennett 2006).

9 This observation has formed the basis of many 'friction of distance' migration models.
} 


\section{The initial spread of farming in Central Europe: the LBK culture}

Fundamental to the debate about the spread of agriculture is the Central European LBK culture, which has been dated from 5700 to $5000 \mathrm{BC}$, and is the earliest agro-pastoralist phenomenon outside the Balkans. Since the first LBK farmers of central Europe were clearly not the direct descendants of local hunter-gatherers, they must have emigrated from another region. As yet, no palaeogenetic data are available to indicate the most probable region of origin of the early LBK farmers (Burger, Thomas 2011. 378). From an archaeological perspective, the most plausible region is around the area of Lake Balaton in present-day Hungary, where the LBK first developed from the predecessor Starčevo culture. The LBK period is typically divided into four chronological phases based on the evolution of ceramic decoration: oldest (5700-5500 BC), older (5500-5300 BC), younger, and youngest (Keeley, Golitko 2004). However, more precise regional chronologies have been developed for most areas of LBK distribution, e.g., Krisztián Oross and Eszter Bànffy (2009) consider three successive waves of Neolithisation in Transdanubia. Much LBK material culture (pottery, lithics, groundstone, ceramic figurines) and the economy have clear ties to the northern Balkan Early Neolithic, while other aspects, most notably the LBK longhouse, are novel. The LBK economy is based almost entirely on domesticated plants and animals and its settlements (ger. Siedlungskammern) are concentrated on fertile loess soils along streams. The LBK culture brought the first farming settlements to central Europe through a movement of farming peoples from the Danube Valley to the north and west and to the central European uplands, as well as to parts of the North European Plain along the Oder and Vistula Rivers. The westernmost sites did not appear until $4900 \mathrm{BC}$, which would indicate that, on average, the LBK culture spread into Europe at a rate of 3.5-5 kilometres per year. By using strontium isotope measurements of human skeletal material from two cemeteries, Douglas Price et al. (2001) demonstrated a high incidence of migration, i.e. LBK farmers were highly migratory and interacted with surrounding communities. Initially, it was believed that LBK communities practiced swidden agriculture or shifting cultivation and that the constant need for new land fuelled the rapid dispersal of LBK peoples into central Europe (Childe 1929). It has since become clear that many LBK sites were settled continuously for several hundred years, i.e. their farming practices were sustainable for hundreds of years on heavy, loess-derived soils (Saqalli et al. 2014). For the most part, the expansion of LBK peoples seems to have halted at the boundaries of the North European Plain (except in Poland), where for as long as a millennium they were in contact with complex hunter-gatherers to the north. After $4800 \mathrm{BC}$, the LBK culture disappeared, but several related 'daughter' cultures emerged, such as the Rössen in western Germany and the Netherlands, the Villeneuve/Saint Germain in France, the Blicquy in Belgium, the Stichbandkeramik (Stroke-Ornamented Pottery culture) in eastern Germany, and the Lengyel in much of the eastern LBK region. The latter culture gave rise to the earliest Funnel Beaker communities (or TRB) in the Polish lowlands, continuing the expansion of agriculture onto the North European Plain and into southern Scandinavia.

LBK archaeological assemblages (domesticated animals and plants, longhouses, pottery) appeared suddenly from the Hungarian plain, near Budapest, to eastern France in a relatively short period in the $6^{\text {th }}$ millennium. Within 700 to 800 years, these peoples had spread through most of central Europe and to the boundary of the North European Plain. With the largest area of the LBK region being about $1500 \mathrm{~km}$ (from Transdanubia to the Paris Basin) and the time taken to spread over that area of about 360 years, the average propagation rate of the LBK could not have been less than $4 \mathrm{~km} /$ year (Dolukhanov et al. 2005). Gronenborn (2003.81) even argues for a migration covering $800 \mathrm{~km}$, from Transdanubia to the Rhine valley, within less than 150 years, which is a viable hypothesis through riverine colonisation, since many central European rivers form a nexus to facilitate this (Davison et al. 2006; Rowley-Conwy 2011; Henderson et al. 2014). Settlers thus covered an average distance of about $800 \mathrm{~km}$ at a rate of at least $5.6 \mathrm{~km} /$ year. The actual propagation speed could have been even higher, as only loess regions were settled.

Traditionally, scholars have made assumptions about the overall uniformity of the LBK culture, which therefore was interpreted as reflecting colonisation events as the one explained by demic diffusion, which in the present case indicated the rapid eastwest orientation of the spread of agro-pastoralist populations. However, this uniformity has increasingly come to be doubted, with the recognition of local and regional variability in the LBK package (Bentley 2007). The latter includes lithic, ceramic, burial and dietary habits etc.; its variability suggests more continuity and the passage of traditions from indi- 
genous hunter-gatherer populations to farmers. Therefore, it remains to explore the mosaic of regional variation within the once uniform LBK culture.

\section{Farmers' spatial behaviour and the differential of soil fertility}

When farmers' migration is - fully or partially - considered as responsible for the spread of farming as it is for instance in the demic diffusion model it is assumed, implicitly or not, that the spread of farming presupposes that spatial expansion would not have been triggered until local populations approached an absolute local carrying capacity. However, this view has been challenged by the variability in the diffusion of agriculture, such as the speed of agricultural expansion into Central Europe. ${ }^{10}$ Indeed, in certain areas, we can see that new places were colonised before others had reached any sort of carrying capacity.

\section{Farmers' spatial behaviour}

The basis for understanding why further expansion does not necessarily presuppose demographic saturation is provided by principles related to decision making concerning spatial behaviour (Fiedel, Anthony 2003; Shennan 2007; 2009). For this purpose, we refer to concepts such as marginal valuation, opportunity cost, discounting, and risk sensitive analysis of microeconomic analysis and human behavioural ecology (Winterhalder, Kennett 2006) which are used in an attempt to assess the costs and benefits of alternative courses of action under a range of environmental conditions. It seems obvious that agricultural communities would choose to settle in areas of high productivity. Less desirable areas (due to economic, climatic, ecologic, ${ }^{11}$ geographic or social barriers) are bypassed in favour of more optimal locations. As these favourable areas become colonised, subsequent colonisation events will take place in the immediate vicinity of the initial colony. Therefore, the radial spread of sites continues outward from the earliest agricultural site in an area. This expands on Ammerman and Cavalli-Sforza's model in that it accounts for differential agricultural productivity in the study region and the desire of emigrants to choose specific locales suited for agriculture. However the variability of agriculture diffusion observed in different regions means that this pattern appears much closer to directed colonisation events than the random short-distance dispersal of daughter communities assumed in the demic diffusion model.

\section{Farmers' access to land under contest compe- tition}

In order to express farmers' spatial behaviour, we first describe what is required for cultivation, in addition to cultigens and labour force, i.e. land. Since our analysis is conducted at a micro or local level, we start by considering a site ${ }^{12}$ (as it is usually defined by archaeologists). This site consists of many patches, and each patch encompasses several territories. In a given patch, the territories are not identical. They differ with respect to soil fertility and thus may be ranked from the best territory (the one with the highest soil fertility) to the worst (where soil fertility is at its lowest level). In a given patch, land is a resource available in limited quantities. Then, its distribution among farmers is consistent with two alternative scenarios concerning competition 13 among farmers coming into that patch.

The first scenario involves simultaneous common exploitation of land. Depending on the approach considered (economics, population ecology, and demography), such a situation is called 'scramble competition' or 'ideal free distribution'. We may simply define it as a situation of open access to land. When farmers move into a new patch, they will occupy first the territories that give them the best returns. As more farmers occupy the patch, the returns to each farmer decline, to the point that the returns to farmers from the best territory are no better than those from the best territory of the next patch, which at this point has no occupants. The returns from both territories are then equal, and they will be occupied indiscriminately until additional incoming farmers are introduced to the point at which there is an equal benefit to be gained from occupying still worse territory, and the process is repeated. Thus, under scramble competition, new incoming farmers reduce the mean return for everybody, including those who arrived first.

If scramble competition may be appropriate to describe competition for access to resources among some species, it is not appropriate to describe land

10 As well as in Southeast and Mediterranean Europe.

11 See e.g., Robert Kertész, Pál Sümegi (2001).

12 Site: a distinct spatial clustering of artifacts, features, structures, and organics and environmental remains - the residue of human activity (Renfrew, Bahn 2012.583).

13 Both scenarios are detailed by Clem Tisdell (2013.Ch. 7). 
competition among farmers; a second scenario must be considered. Indeed, open access to land is relevant to describing a foraging economy. While foraging is associated - most of the time - with an immediate-return economy (Woodburn 1982), farming necessitates many 'investments' (such as ploughing, sowing, weeding, irrigating ...) before crops can be harvested. Farming is thus intrinsically associated with a delayed-return economy. Therefore, any farmer will have incentives to incur the investments previously described if, and only if, he owns in the future the output resulting from these investments. This condition is fulfilled if there is territoriality, or contest competition. It results in individuals staking out rights to the limiting resource (land in our case) and defending these usually by aggression. In most cases, this involves creating exclusive territories where the incumbent has exclusive rights to the limiting resources within his territory.

In our present case study, contest competition means that property rights related to land ownership are introduced. Indeed, such introduction is completely consistent with - and even necessary to - the transition from foraging to farming, since as stated by Douglass C. North and Robert P. Thomas (1977. 230), "The key to our explanation (of the transition from foraging to farming) is that the development of exclusive property rights over the resource base provided a change in incentives sufficient to encourage the development of cultivation and domestication".

Under contest competition, even if all farmers of a given patch are working the same amount of time every day, their labour productivity will differ as well as income. This results from the combination of the difference of soil fertility between territories, and the introduction of territoriality. In other words, contest competition among farmers is naturally associated with economic (and social) inequalities. Based on archaeological evidence 14 related to LBK settlements and cemeteries located in the western Rhineland, Stephen Shennan (2009.347) observes that "Over time these local LBK societies do indeed seem to have become more unequal", a situation which can result from contest competition among farmers concerning access to land. A similar conclusion is reached by Alexander R. Bentley et al. (2012). Indeed, from isotopic analysis of human skeletons, these authors derive evidence concerning forms of social organisation and differentiation at the population scale from across the LBK distribution.

\section{The differential of soil fertility and farmers' migration}

Under contest competition - also called ideal despotic distribution - the first incoming farmer into an unoccupied patch is able to select the best territory. Since the latter has the best soil fertility, it is in this territory that the marginal productivity of labour (and thus the farmer's income) will be at its highest level. The second incoming farmer will select the second best territory; as a result, his income will be lower than the one earned by the first incoming farmer. The same logic applies to subsequent incoming farmers who decide to remain in the initial patch. From this, we may deduce a general principle associated with contest competition: in contrast to what happens in scramble competition, in contest competition, the farmers' returns depend on their order of settlement in the patch. Indeed, subsequent incoming farmers settling there do not affect the income of incumbent farmers. Since each additional incoming farmer has to take the next best territory, and therefore earns less than the previous incomer, there comes a critical point at which the next settler will do just as well by taking the best territory in the next patch. At this critical point, the farmer's spatial optimal behaviour means a shift from the initial patch to the next patch, i.e. it leads to migration. Indeed, at any moment, any incoming farmer takes his decision about spatial location by comparing:

- on the one hand, the return associated with a territory of the initial patch, the latter being partially occupied by incumbent farmers. It should be noted that this return is decreasing with increasing demographic density in the initial patch;

- on the other hand, the return provided by the best territory of the next patch, which is unoccupied.

As long as the differential between both returns is exceeded by the cost of transportation from the initial patch to the next patch, the farmer remains in the initial patch, i.e. he does not migrate. Symmetrically, when this differential is larger than the cost of transportation, the farmer decides to migrate to the next patch.

It is thus possible to derive a general result from the previous statement: the higher the demographic

14 For example, the site of LW8 in the Merzbachtal in the Aldenhovener Platte region of western Rhineland, which was established in the $52^{\text {nd }}$ century BC and was occupied throughout the approx. 400 years of the local LBK sequence. 
density in the initial patch, the lower will be the return of the marginal farmer coming into that patch, and the more this farmer will be willing to migrate to the next patch. In other words, throughout the influence of the differential of soils fertility, demographic density fosters migration, i.e. the spread of agriculture. This result is in fact the simple transposition at the local level of the belief that at a macro level population growth constitutes a push factor of migration (and then also of the spread of agriculture).

As a remark, we have assumed that the differential of returns reflects the differential in soil fertility between territories. Implicitly, this means that other factors, such as technology, ecological conditions or climate, do not have an influence on agricultural returns. Indeed, without loss of generality, we may assume that at the local level, all farmers have the same technology. Furthermore, we may also assume that at the local level, ecological conditions and climate have the same influence on the various patches of the site. In other words, the only difference at the local level - in agriculture productivity results from differences in soil fertility.

\section{Agglomeration economies and cumulative cau- sation}

We have previously demonstrated that the higher demographic density may imply migration, since it reduces the income provided by agriculture production of any incoming farmer. However, a higher demographic density should have an opposite effect on the farmer's income since it induces agglomeration economies in the initial patch. Such agglomeration economies are associated with geographical concentration of activities and have been studied in economics for several decades.

\section{The New Economic Geography}

In the 1950s, some development economists used a variety of concepts - such as Gunnar Myrdal's (1957) 'circular and cumulative causation', or Albert 0 . Hirschman's (1958) 'forward and backward linkages' to emphasise that large markets are those where more firms and workers locate. From the early 1990s, New Economic Geography (hereinafter NEG) - an economic approach mainly lead by Paul Krugman (1991) - has formalised this kind of cumulative causation mechanism, to show that regions which are similar or even identical in underlying structure can endogenously differentiate into rich 'core' regions and poor 'peripheral' regions. Thus, and as stated by Masahisa Fujita and Paul Krugman (2004. 140), NEG is a body of research which fundamentally attempts "to explain the formation of a large variety of economic agglomeration (or concentration) in geographical space". Most of the concepts and tools employed by NEG, as well as the ambiguous impact of economic integration on development, were well-known before NEG's appearance. In fact, the innovative contribution of NEG consists of the rigorous formalisation of such concepts, which basically allows us to account for the dynamics of spatial clustering (and dispersal) of economic activity. Since there are several mechanisms through which cumulative causation may arise, we may successively consider all of them in our framework devoted to farmers' spatial behaviour.

As highlighted in the previous section, transport costs - which of course are included in NEG - are a crucial element influencing location choices. The impact of transport costs on farmers' location choices clearly depends on the level of such costs. As a consequence, any farmer decides whether it is more convenient to concentrate in just a single location, the initial patch, or alternatively to incur additional cost in order to migrate in a different location, the next patch. In other words, the level of transport costs constitutes a crucial force towards agglomeration (or dispersal) in farmers' location behaviour.

\section{Marshallian sources of external economies}

NEG incorporates external economies; in doing this, NEG essentially recalls Alfred Marshall's (1890) insights about externalities. Several sources of external economies can be identified in a farming context.

Firstly, any economic concentration supports a concentrated local labour market, especially for specialised skills, so that employees find it easier to find employers and vice versa. Therefore, farmers that cluster in a single location take advantage of the availability of a pooled labour force endowed with agricultural-specific skills. In fact, the labour for most cultivation-related tasks is organised within two forms: the household and kin, and community work groups. Household labour by itself suffices for very few plot-related tasks, the most significant of which is watching the crops. Community-level labour is the main form of labour deployment, which can ensure the successful completion of the cycle, from clearing forest to harvest. Thus, the agglomeration of farmers connected with a local pooled labour market leads to an increase in efficiency in farming activities. 
Secondly, there are some market-size effects. Hence, when farmers concentrate production in a given patch they also take advantage of the presence of specialised suppliers of intermediate goods and inputs such as tools (e.g., digging stick, hoe, ard, stone axe, mortar and pestle ...). These are so-called 'forward linkages', because a large local market supports the local production of intermediate goods, lowering costs for downstream farmers. One may also note that the development of the agrarian economy leads to a more intensive division of labour among farmers. This has two consequences: it increases specialisation and thus farmers' productivity, and leads to the release of labour from food production. The latter means that many job opportunities appear, which in turn implies the emergence of non-food specialists (such as craft specialists, bureaucrats, priests, soldiers and chiefs). According to Jacob L. Weisdorf (2003.19), "If the adoption of more productive food procurement methods went hand in hand with the emergence of non-food specialists, the rise of agriculture bore the seeds for the later process of industrialisation and thus for economic growth".

Thirdly, a local concentration of economic activity may create more or less pure external economies via information spillovers and technological externalities. Thus, clustered farmers are supposed to benefit from technological spillovers consisting of unintentional flows of knowledge arising from proximity to one another and benefitting all farmers 1ocated on the same patch. As a result, farmers are encouraged to localise in a single place to benefit from external knowledge arising from other farmers' activities.

It should be noted that such technological externalities were more likely to occur during the early stages of agricultural expansion into Central Europe. Indeed, the continental climate and the ecosystem of Central Europe are very different from the Mediterranean climate and biome, where agriculture first originated (the Fertile Crescent) and then spread (Greece and the Balkan Peninsula). Moreover, geographic and biogeographic conditions do not have a separate, but combined, influence on plants and animals. Indeed, every plant or animal has certain habitat and environmental preferences. As such, they can only be cultivated and bred within their toler- ance limits. 15 Therefore, the climatic and ecological adaptation of cultigens and domesticated animals was a great task for the first farmers migrating into Central Europe. Thus, the success of this adaptation is due to a large extent to information spillovers and technological externalities between farmers belonging to a same cultural group, such as the LBK culture.

\section{Clustering and migration}

Even if land, which is an immobile factor of production, militates against concentrations of production, we have identified several sources of external economies in a farming context, such as labour market pooling, availability of the specialised intermediate products and technological spillover effects. All these sources of external economies may be viewed as possible reasons why farmers tend to cluster together ${ }^{16}$ in a given patch, i.e. why they do not migrate. More deeply, any of these external economies is positively correlated with the number of farmers remaining in the initial patch, i.e. with demographic density. In other words, when agglomeration economies or external economies related to clustering are taken into account, demographic density hinders migration.

\section{Agriculture and increasing returns}

It is well known that increasing returns to scale are acknowledged to be fundamental for NEG when accounting for the spatial unevenness of economic activity, since by definition they stimulate the spatial clustering of economic production. Thus, conventional economists would argue that there is a problem in our previous statement, since agricultural systems are usually subject to diminishing returns caused by limited amounts of fertile land. However, this claim can be challenged for early Neolithic agricultural systems. Indeed, we may assume, as Weisdorf (2005. 570) did, that "farming exhibits constant returns to labour, a fair assumption given the abundance of suitable land at that time".

Since fertile land was obviously unlimited at the beginning of the Neolithic in Central Europe, we may even go further, as Peter Bogucki (2000) did. This author considers that, after a demanding initial investment, with the adaptation of cultigens and livestock to central European habitats, accumulated experience led to a progressively greater understanding of soils, climate, landforms, plants, and animals. Therefore, the introduction of agriculture to Central

15 This phenomenon is called the minimum limiting factor (Liebig 1840).

16 Sergei Fedotov et al. (2008) develop a model for population migration and the growth of human settlements during the Neolithic transition; the numerical results show that the individual farmers have a tendency for aggregation and clustering. 
Europe was very much a knowledge-based process, and such processes are usually largely subject to increasing returns. Thus, we may even assume that during the early ages of agricultural diffusion, farming was associated with increasing returns, the latter increasing the magnitude of the external economies related to geographical concentration, as described above.

\section{Demographic density dependence of reproduc- tion and survival conditions}

Under contest competition among farmers, we have demonstrated in a section above a general and quite intuitive result: throughout, the influence of the differential of soils fertility, demographic density fosters migration, i.e. the spread of agriculture. This result is in fact the simple transposition at the local level of the macro-level mechanism, which states that population growth, constitutes a migration push factor. We assumed as well that a farmer who migrated from the initial patch to the next (unsettled) patch would not incur additional costs, except for transport. Here, we release this strong assumption. Indeed, any migrant takes the risk of finding and settling a new top-quality territory in the next patch, which may be located some distance away. More precisely, the first migrants, and especially the first one, will be the first occupants of the next patch that has not been settled. Thus, the first migrant-occupant may have some disadvantages, such as limited access to reproductive partners or lack of local support if crops fail. In other words, for the first migrants into the next patch, demographic density will be extremely low (and even nil for the first migrant), implying many disadvantages related to their reproduction and survival. This positive correlation between population density and individual fitness is the so-called Allee effect.

\section{The Allee effect}

The classical view of population dynamics states that, due to competition for resources, a population will experience a reduced overall growth rate at higher density and increased growth rate at lower density: this is the so-called 'logistic growth'. Such a view is implicitly associated with Charles Darwin and his concept of the 'struggle for survival'. However, even Darwin was worried that his notions of 'struggle' and intense competition for survival would obscure the importance of cooperation 17 (Lidicker
2010.72). In the early 1930 s and through experimental studies (on fish populations), Warder C. Allee (1931) demonstrated the positive correlation between population density and individual fitness, i.e. a result opposite to Darwin's struggle for life. Allee concluded that aggregation can improve the survival rate of individuals, and that cooperation may be crucial in the overall evolution of social structure. Then, he defined effects that are classified by the nature of density dependence at low densities. There is a weak Allee effect if the per capita growth rate is positive and increasing and a strong Allee effect if the population shrinks for low densities, i.e. when per-capita growth rate is negative below a threshold density.

Since Allee's (1931) seminal work, the presence and the role of his effect have been widely studied in population ecology, from which numerous evidence of its existence are provided (see for instance $\mathrm{Kra}$ mer et al. 2009) and also with respect to individual behaviour (Sutherland 1996). It is thus possible to consider the existence and the role of the Allee effect related to farmer's spatial behaviour.

\section{The mechanisms underlying the Allee effect}

Due to its definition as a positive correlation between population density and average fitness, the mechanisms which cause the Allee effect are therefore inherently tied to survival and reproduction. These Allee effect mechanisms arise from a lack of cooperation or facilitation among farmers at low demographic density.

Firstly, the first migrants into the next (unsettled) patch could encounter difficulties related to their reproduction due to mate limitation. The latter refers to the difficulty of finding a compatible and receptive mate for sexual reproduction at lower population size or density, and thus to avoid inbreeding, i.e. the production of offspring from the mat ing or breeding of individuals that are closely related genetically.

Secondly, the first migrants into the next (unsettled) patch could encounter difficulties related to their survival due to their exposures to serious risks. For instance, the first migrants could be in a precarious situation due to the lack of local support if their crops failed. Indeed, simpler, traditional and small-scale societies - such as the farming society prevailing in the initial patch - are usually characte-

17 This led Darwin to ponder the evolution of sociality in insects. 
rised by 'mechanical solidarity'. 18 In a society exhibiting mechanical solidarity, its cohesion and integration comes from the homogeneity of individuals, since people feel connected through similar work, religion and beliefs, and lifestyle. When it exists, such solidarity is based on kinship ties of familial networks; however, when demographic density is too low in the next patch, we may conjecture that these ties become too weak, whereupon the solidarity among migrants disappears. Such a situation may even lead to site abandonment by early farming communities. 19

Another possible problem for the first migrants is protecting themselves against invasion by group anti-invader behaviour. Mark Golitko and Lawrence H. Keeley (2007.333) recall that a number of wellknown LBK contexts demonstrate that violence was often quite severe during the early Neolithic of Central Europe. In addition to evidence of traumatic injuries and massacres, these authors provide evidence of group defence behaviour against invaders, such as the existence of enclosed LBK settlements, which they interpret as fortifications. 20 They finally show that there is a clear association between enclosed sites and remains that can be taken as immediate evidence of conflict. Whether this resulted from direct competition between local hunter-gatherers and competing LBK groups is under investigation; this kind of evidence can only be partly helpful. Indeed, the burials and the traumatic injuries can be considered as evidence of ritual behaviour rather than of inter-group warfare. They can also be the result of warfare within a group or between groups of hunter-gatherers, or between hunter-gatherers and farmers. Neus Isern et al. (2012) explain that the slowdown in the Neolithic rate of spread in Northern Europe can be related to a high indigenous population density hindering the advance as a result of competition for space between the two populations. However, and as pointed out by Golitko and Keeley (2007. 340), "... much of this violence seems to have involved LBK communities fighting each other, as indicated by the mass graves at Talheim and SchletzAsparn ..." In other words, most of the evidence of LBK violence is related to the late phase and therefore conflicts between hunter-gatherers and LBK people are not likely to be the reason for fortification efforts or the evidence of traumatic injuries.
Thus, farmers not only face high risks, but they also need to spend time, energy and resources defending themselves, building walls, manning watchtowers, guarding herds and patrolling fields. This means less time and energy and fewer resources devoted to food production. It could even happen that the greater productivity of the hours they spend growing and raising food is outweighed by the greater time they must spend defending themselves and the food they have grown, meaning that they produce less food in total. But, as stated by Robert Rowthorn and Paul Seabright (2010.3), despite these drawbacks, "What makes the difference (...) is a crucial externality in the technology of defense". However, we believe that such externality exists only when the demographic density of farmers is sufficiently high, which is not the case in the next patch when the first migrants are incoming. Therefore, and to cope with this problem of defence, incoming farmers may increase their vigilance, but the latter will result in less time and energy spent on farming, thus reducing the fitness of farmers living in smaller groups.

\section{Allee effect and migration}

For the first migrants, the demographic density in their patch will be very low. Therefore, there will be, as explained above, an Allee effect related to their reproduction and their survival. Any farmer from the initial patch who intends to migrate into the next patch will expect the existence of these disadvantages. It is thus possible to derive a general result: the higher the differential of demographic density between patches, the higher the Allee effect in the next patch, and fewer farmers on the initial patch will be willing to migrate. In other words, when Allee effects are taken into account by farmers in their spatial behaviour, high demographic density at home hinders migration (weak Allee effect) or may even stop it (strong Allee effect).

\section{Coordination failure between farmers and co- operation with indigenous populations}

We have previously demonstrated that, even when it is derived from farmers' optimal spatial behaviour, migration could be hindered and even stopped. The latter occurs when for a high demographic den-

18 A concept defined by Emile Durkheim.

19 Bogucki (1996) provides evidence of sites abandonment in post LBK North Poland between 4300 and $4000 \mathrm{BC}$ and presents the various explanations provided in the archaeological literature.

20 They also highlight (Golitko, Keeley 2007.337) several features of LBK settlements for which only a military function is appropriate: V- or Y-sectioned enclosure ditches, and complex forms of gates: baffled, offset, crab-claw, labyrinthine or screened. 
sity in the initial patch, there are a low differential of soils fertility between patches, strong agglomeration effects and a strong Allee effect.

\section{Coordination failure and multiple equilibria} In such a situation, any farmer from the initial patch decides not to migrate. At the site level, the distribution of farmers between the two patches can thus be described by a 'status quo equilibrium', i.e. all farmers remain in the initial patch and the next patch remains empty. However, others' equilibrium exists, due to strong spill-over effects between patches, which Pareto-dominate the status quo equilibrium. Indeed, if spill-overs are strong enough, multiple equilibrium outcomes may occur, some of which are better for every farmer than the alternatives, but with no tendency for market forces to lead from the worse to the better state of affairs; thus a problem of coordination failure exists (Hoff 2001). For instance, we may consider, without loss of generality, that an equilibrium associated with an iso-distribution of the farmer population between the two patches provides a higher level of welfare to all farmers.

\section{Massive colonisation}

In order to avoid the problem of coordination failure presented above, and thus to recover a positive rate of expansion when migration stops, the solution consists in avoiding low demographic density in the next patch. Such an intriguing solution may, however, be the result of two different processes.

The first is a massive movement of farmers from the initial patch to the next patch. If it occurs, since the first migrants will be immediately numerous, they will benefit from agglomeration effects and good conditions regarding their reproduction and survival. It could be argued, however, that massive migrations were less likely to occur in the early Neolithic, since colonisation by farmers required substantial logistical planning and harnessing of resources to move a viable population not only of people, but also animals and seed-corn (Fiedel, Anthony 2003). Indeed, evidence of planed massive colonisation occurs only from the Bronze Age, with the early Greek civilisation, for instance.

\section{Acculturation of indigenous populations}

The second process consists of farmers' cooperative strategy with hunter-gatherers. Such a process can indeed lead to the acculturation of hunter-gatherers, i.e. can ease the transition of the latter from foraging to farming. Therefore, the number of settled farmers in the next patch could increase considerably very fast, including 'true' farmers migrating from the initial patch and former hunter-gatherers who were previously foraging in the surrounding area.

Acculturation can result from various contacts between farming and foraging communities, such as intermarriage, the exchange of information or trade (Dennell 1985). For instance, Galeta and Bruzek (2009) demonstrate that the demographic conditions necessary for colonisation were beyond the potential of the Neolithic population and thus support the integrationists' view of the Neolithic transition in Central Europe. In other words, they consider that the establishment of LBK farming communities in Central Europe without an admixture with foragers was highly improbable. In their 'availability model', Marek Zvelebil and Peter Rowley-Conwy (1984) describe a process of acculturation in three phases. Exchange of prestigious goods characterises the first, or availability, phase. More intensive trade characterises the second, the substitution phase. In the third, the consolidation phase, these authors consider that the acculturation process is completed.

While the spread of farming had traditionally been accepted as an example of agricultural colonisation by LBK farmers, it has recently become increasingly apparent 21 - from evidence of contact and interaction between local hunter-gatherers and the earliest farming communities (Gronenborn 1999; Price et al. 2001) - that a scenario such as the one described above provides a plausible explanation for the situation in some areas of Central Europe. For instance, concerning the LBK formation in Transdanubia, Oross and Bánffy (2009), there is evidence that the late Mesolithic settlements and their occupants played a major role in the transformation of the terminal Starčevo culture. In addition, molecular approaches using non-recombining genetic marker systems (mitochondrial DNA and Y-chromosome) have indicated a contribution of Neolithic Near-Eastern lineages to the gene pool of modern Europeans of around a quarter or less (Richards 2003). According to this analysis, even the highest Neolithic impact, this was on southeast Europe, central Europe, and northwest and northeast Europe, is between $15 \%$ and $22 \%$ of Neolithic lineages. 


\section{Conclusion}

The migrationist approach to the spread of agriculture can be divided into two different points of view. For the first, the spread is considered on a macroscale, such as the European continent, and over a long period (the period associated with the complete Neolithisation of Europe). In such approach, the demic diffusion model seems to provide a convincing explanation. According to this model, the spread was a slow, regular and haphazard process. The motives of migration (soil depletion, conflict or warfare, population pressure) are assumed to have been exogenous to farmers. Similarly, factors which hinder the spread of agriculture - e.g., ecological, geographical or cultural barriers - are also considered exogenous.

In this paper, we favour a second view in which the spread is considered at a spatial micro scale. At the regional level, as illustrated by the spread of LBK in Central Europe, archaeological records provide evidence of extreme variability in the rate of farming expansion. Since environmental conditions are quite homogeneous at this regional level - and above all, homogeneous at the site level - migration must be considered as a deliberate process resulting from farmers' spatial behaviour. We highlight two effects - agglomeration effects and the Allee effect - which endogenously influence farmers' decision making and therefore the rate of farming expansion. When both effects are weak, they contribute to the rapid expansion of agriculture, as experienced by the LBK culture from Transdanubia to the Rhine valley, when $800 \mathrm{~km}$ were covered in approx. 150 years. On the contrary, when both effects are strong, they may hinder or even stop the migration process, as experienced by the LBK culture in Northern Europe, where, despite contacts with indigenous populations, the expansion stopped for 1500 years. The magnitude of both effects exhibits demographic density dependence. When at a given site settled by farmers, the demographic density is low (respectively high), both effects are weak (respectively strong). Therefore, when both effects are taken into account, they help to explain the counter-intuitive, but observed, negative correlation between demographic density and the rate of expansion. Thus our view provides a significant contribution to understanding the spread of the Neolithic by bridging macro/micro approaches.

\section{$\therefore$}

\section{References}

Allee W. C. 1931. Animal Aggregations, a Study in General Sociology. University of Chicago Press. Chicago.

Ammerman A. J., Cavalli-Sforza L. L. 1971. Measuring the rate of spread of early farming in Europe. Man 6: 674688.

1984. The Neolithic Transition and the Genetics of Populations in Europe. Princeton University Press. Princeton.

Bentley R. A. 2007. Mobility, specialisation and community diversity in the Linearbandkeramik: isotopic evidence from the skeletons. In A. Whittle, V. Cummings (eds.), Going over: the Mesolithic-Neolithic transition in northwest Europe. British Academy. London: 117-140.

Bentley R. A., Bickle P., Fibiger L., Nowell G. M., Dale C. W., Hedges R. E. M., Hamilton J., Wahl J., Francken M., Grupe G., Lenneis E., Teschler-Nicola M., Arbogast R.-M., Hofmann D. and Whittle A. 2012. Community differentiation and kinship among Europe's first farmers. Proceedings of the National Academy of Sciences of the United States of America 109(24): 9326-9330.
Bocquet-Appel J.-P., Naji S., Vander Linden M. and Kozłowski J. 2012. Understanding the rates of expansion of the farming system in Europe. Journal of Archaeological Science 39(2): 531-546.

Bogucki P. 1996. Sustainable and Unsustainable Adaptations by Early Farming Communities of Northern Poland. Journal of Anthropological Archaeology 15: 289-311.

2000. How agriculture came to north-central Europe. In T. D. Price (ed.), Europe's First Farmers. Cambridge University Press. Cambridge: 197-218.

Burger J., Thomas M. G. 2011. The Palaeopopulationgenetics of Humans, Cattle and Dairying in Neolithic Europe. In R. Pinhasi, J. T. Stock (eds.), Human Bioarchaeology of the Transition to Agriculture. John Wiley \& Sons, Ltd. Chichester: 371-384.

Childe V. G. 1929. The Danube in prehistory. Clarendon Press. Oxford.

1936. Man makes himself. Watts. London. 
Davison K., Dolukhanov P., Sarson G. R. and Shukurov A. 2006. The role of waterways in the spread of the Neolithic. Journal of Archaeological Science 33: 641-652.

Dennell R. 1985. The hunter-gatherer/agricultural frontier in prehistoric temperate Europe. In S. Green, S. Perlman (eds.), The Archaeology of Frontiers and Boundaries. Academic press. Orlando: 113-140.

Divišová M. 2012. Current Knowledge of the Neolithisation Process: a Central European Perspective. Interdisciplinaria Archaeologica. Natural Sciences in Archaeology II(1): 141-153.

Dolukhanov P., Shukurov A., Gronenborn D., Sokoloff D., Timofeev V. and Zaitseva G. 2005. The chronology of Neolithic dispersal in Central and Eastern Europe. Journal of Archaeological Science 32: 1441-1458.

Fedotov S., Moss D. and Campos D. 2008. Stochastic model for population migration and the growth of human settlements during the Neolithic transition. Physical Review E 78(2 Pt 2): 026107.

Fiedel S. J., Anthony D. W. 2003. Deerslayers, pathfinders and icemen. Origins of the European Neolithic as seen from the frontier. In M. Rockman, J. Steele (eds.), The Colonization of Unfamiliar Landscapes: The Archaeology of Adaptation. Routledge. London: 144-168.

Fisher R. A. 1937. The Wave of Advance of Advantageous Genes. Annals of Eugenics 7: 355-369.

Fort J. 2015. Demic and cultural diffusion propagated the Neolithic transition across different regions of Europe. Journal of Royal Society Interface 12: 20150166. http:// dx.doi.org/10.1098/rsif.2015.0166

Fujita M., Krugman P. 2004. The New Economic Geography: Past, present and the future. Papers in Regional Science 83: 139-164.

Galeta P., Bruzek J. 2009. Demographic model of the Neolithic transition in Central Europe. Documenta Praehistorica 36: 139-150.

Gkiasta M., Russell T., Shennan S. and Steele J. 2003. Neolithic Transition in Europe: The Radiocarbon Record Revisited. Antiquity 77(295): 45-62.

Golitko M., Keeley L. 2007. Beating ploughshares back into swords: warfare in the Linearbandkeramik. Antiquity 81 (312): 332-342.

Gronenborn D. 1999. A variation on a basic theme: the transition to farming in southern central Europe.Journal of World Prehistory 13: 123-210.
2003. Migration, acculturation and culture change in western temperate Eurasia, 6500-5000 cal BC. Documenta Praehistorica 30: 79-91.

Henderson D. A., Baggaley A. W., Shukurov A., Boys R. Y., Sarson G. R. and Golightly A. 2014. Regional variations in the European Neolithic dispersal: the role of the coastlines. Antiquity 88(342): 1291-1302.

Hirschman A. 0. 1958. The Strategy of Economic Development. Yale University Press. New Haven.

Hoff K. 2001. Beyond Rosenstein-Rodan: The Modern Theory of Coordination Problems in Development. In Proceedings of the Annual World Bank Conference on Development Economics, 2000 (Supplement to the World Bank Economic Review). World Bank. Washington DC: 145-188.

Isern N., Fort J. and Vander Linden M. 2012. Space Competition and Time Delays in Human Range Expansions. Application to the Neolithic Transition. PLOS ONE 7(12): e51106. doi:10.1371/journal.pone.0051106.

Keeley L. H., Golitko M. 2004. First Farmers of Central Europe. In P. Bogucki, P. J. Crabtree (eds.), Ancient Europe; 8000 B.C. - 1000 A.D. Encyclopaedia of the Barbarian World. Charles Scribners \& Sons. New York: 259-266.

Kertész R., Sümegi P. 2001. Theories, critiques and a model: why did the expansion of the Körös-Starčevo culture stop in the centre of the Carpathian Basin? In R. Kertész, J. Makkay (eds.), From the Mesolithic to the Neolithic. Archaeolinqua Press. Budapest: 225-246.

Kind C.-J. 2010. Diversity at the transition - a view from the Mesolithic. In D. Gronenborn, J. Petrasch (eds.), The spread of Neolithic to Central Europe. International Symposium, 24 June-26 June 2005. Mainz: 449-460.

Kramer A. M., Dennis B., Liebhold A. M. and Drake J. M. 2009. The evidence for Allee effects. Population Ecology 51: 341-354. DOI 10.1007/s10144-009-0152-6.

Krugman P. 1991. Geography and Trade. MIT Press. Cambridge.

Lee E. S. 1966. A theory of migration. Demography 3: 4757.

Lewis G. L. 1982. Human Migration. Croom Helm Ltd. London.

Lidicker, Jr. W. Z. 2010. The Allee Effect: Its History and Future Importance. The Open Ecology Journal 3: 71-82. 
Liebig J. 1840. Organic Chemistry and its Application to Agriculture and Physiology. Taylor and Walton Press. London.

Marshall A. 1890. Principles of economics. Macmillan. London.

Myrdal G. 1957. Economic Theory and Under-developed Regions. Duckworth. London.

North D. C., Thomas R. P. 1977. The first economic revolution. The Economic History Review Second Series 30: 229-241.

Oross K., Bánffy E. 2009. Three successive waves of Neolithisation: LBK development in Transdanubia. Documenta Praehistorica 36: 175-189.

Pinhasi R., Fort J. and Ammerman A. J. 2005. Tracing the Origin and Spread of Agriculture in Europe. PLOS Biology 3(12): e410, 2220-2228.

Price T. D. 2000. Europe's first farmers: an introduction. In T. D. Price (ed.), Europe's First Farmers. Cambridge University Press. Cambridge: 1-18.

Price T. D., Bentley R. A., Lüning J., Gronenborn D. and Wahl J. 2001. Prehistoric human migration in the Linearbandkeramik of Central Europe. Antiquity 75(289): 593603.

Renfrew C., Bahn P. 2012. Archaeology. Theories, Methods and Practice. Thames and Hudson Ltd. London.

Richards M. 2003. The Neolithic invasion of Europe. $A n$ nual Review of Anthropology 32: 135-162.

Rowley-Conwy P. 2011. Westward Ho! The Spread of Agriculturalism from Central Europe to the Atlantic. Current Anthropology 52(S4): S431-S451.

Rowthorn R., Seabright P. 2010. Property Rights, Warfare and the Neolithic Transition. IDEI Working Paper 654 (November). Available from http://idei.fr/display.php $? \mathrm{a}=23850$.

Saqalli M., Salavert A., Bréhard S., Bendrey R., Vigne J-D. and Tresset A. 2014. Revisiting and modelling the woodland farming system of the early Neolithic Linear Pottery Culture (LBK), 5600-4900 B.C. Vegetation History and Archaeobotany 23(1): 37-50.

Shennan S. 2007. The spread of farming into Central Europe and its consequences: evolutionary models. In T.
Kohler, S. E. Van der Leeuw (eds.), The Model-Based Archaeology of Socionatural Systems. School of American Research Press. Santa Fe NM: 141-156.

2009. Evolutionary Demography and the Population History of the European Early Neolithic. Human Bio$\log y$ 81(2-3): 339-355.

Sutherland W. J. 1996. From Individual Behavior to Population Ecology. Oxford University Press. Oxford.

Svizzero S. 2015. The Long-Term Decline in Terms of Trade and the Neolithization of Northern Europe. Scandinavian Economic History Review. Forthcoming. DOI: 10.1080/03585522.2015.1008566.

Tisdell C. A. 2013. Competition, Diversity and Economic Performance. Edward Elgar. Cheltenham.

van Andel T. H., Runnels C. N. 1995. The earliest farmers in Europe. Antiquity 69(264): 481-500.

Weisdorf J. L. 2003. Stone age economics: The origins of agriculture and the emergence of non-food specialists. Discussion Paper 03-34. Institute of Economics. University of Copenhagen. Copenhagen.

2005. From foraging to farming: explaining the Neolithic Revolution. Journal of Economic Surveys 19(4): 561-586.

Winterhalder B., Kennett D. J. 2006. Behavioral Ecology and the Transition from Hunting and Gathering to Agriculture. In D. J. Kennett, B. Winterhalder (eds.), Behavioral Ecology and the Transition to Agriculture. University of California Press. Berkeley: 1-21.

Woodburn J. 1982. Egalitarian Societies. Man 17(3): 431451.

Zilhão J. 2001. Radiocarbon Evidence for Maritime Pioneer Colonization at the Origins of Farming in West Mediterranean Europe. Proceedings of the National Academy of Sciences of the United States of America 98 (24): 14180-14185.

Zvelebil M. 2001. The agricultural transition and the origins of Neolithic society in Europe. Documenta Praehistorica 28: 1-26.

Zvelebil M., Rowley-Conwy P. 1984. Transition to farming in northern Europe: a hunter-gatherer perspective. Norwegian Archaeology Review 17: 104-127. 